[Jap. J. Sanit. Zool. Vol. 25 No. 1 p. $57 \sim 64$ 1974]

\title{
Studies on the ovarian development in the housefly Musca domestica vicina Macquart
}

\author{
II. Effect of a chemosterilant, hempa, on the \\ ovarian development
}

\author{
Hironori SAKURAI \\ Department of Medical Zoology, Nagoya University School of Medicine, \\ Showa-ku, Nagoya 466, Japan
}

Received: January 28, 1974)

\begin{abstract}
Sterilizing effect of hempa was studied in relation to the ovarian development of the housefly, Musca domestica vicina Macquart. Continual treatment with low concentration of hempa below $0.02 \%$ to both sexes of the flies induced decline of hatchability of eggs laid during the treatment; decrease of egg production and complete sterility were observed by the treatment of high concentration above $0.1 \%$. Flesh weight and follicle size of the ovary at 4 days after emergence decreased intensely by the treatment with the high concentration of hempa. Histological observations demonstrated that treatment with low concentration of hempa induced vacuolization of the ooplasm of the mature follicle, and that the high concentrations induced pycnosis and degradation of the nuclei of the nurse and follicular epithelial cells, collapse of the germarium and lack of the enlargement of the 2nd-follicles. Conspicuous vacuolization was also observed in the fat body of females. Histological changes described above indicate that the effect of hempa is, in addition to its known effect of inducing male sterility, concerned to induce sterility in female housefly.
\end{abstract}

\section{INTRODUCTION}

Ovarian development of the housefly was studied histologically and biochemically, and function of the follicle during oogenesis was described in the previous paper (Sakurai, 1973). In order to analyze the function of the follicle, studies on the mechanism that induces female sterility are also important subjects. On the similar point of view, ovarian tumors and radiation induced abnormalities were studied in the ovary of Drosophila melanogaster (King, $1957 \mathrm{a}, \mathrm{b}$; King et al., 1957). Hempa (hexamethylphosphoric triamide) is known as one of the non-alkylating chemosterilants with its low toxicity against mammals (Chang et al., 1964). However, no detailed analysis has

桜井宏紀：名古屋大学医学部医動物学教室（名古屋 汿昭和区鶴舞町 65) been made with respect to its effect on oogenesis.

In this paper, sterilizing action of hempa will be reported in close relation to the oogenesis of housefly.

\section{MATERIALs and Methods}

Houseflies belonging to the Takatsuki strain were used for the experiment. Larvae were reared at $25^{\circ} \mathrm{C}$ on the medium containing wheat-bran and fish-powder $(2: 1)$. Both sexes of the newly emerged houseflies were caged together and fed 5\% milk solution containing various amounts of hempa throughout the experiment.

To see the effect of hempa on the reproduction, egg production and hatchability were scored on the eggs laid for 10 days after the emergence. Per cent sterility (S) was calculated according to the following 
formula :

$$
\begin{aligned}
S= & \left(1-\frac{v^{\prime}}{v}\right) \times 100 \\
& \left(\begin{array}{c}
v ; \text { viability of egg of normal flies } \\
v^{\prime} ; \text { viability of eggs of treated flies }
\end{array}\right)
\end{aligned}
$$

To observe the ovarian development, the $\mathrm{CO}_{2}$-anesthetized females at 4 days after emergence were dissected in $0.9 \%$ saline. Flesh weight of the ovary was determined gravimetrically, and length of the first follicles was determined along the long axis under the binocular microscope.

For histological observation, the ovaries or the abdomens of females at 4 days after emergence were fixed in $10 \%$ formalin or Bouin's fluid. Afer fixing, the specimens were dehydrated and embedded in paraffin. Serial sections of $5 \mu$ thickness were stained with Delafield's hematoxylin and eosin.

\section{RESULTS}

\section{Effect of hempa on the reproduction}

Continual feeding with high concentration of hempa above $0.5 \%$ caused death of the majority of flies within 4 days and none survived beyond 6 days after their emergence. No lethal effect was observed within 4 days after the emergence by the treatment of hempa below $0.25 \%$ concentration, and about 70 and $50 \%$ mortalities were noted in 0.25 and $0.1 \%$ hempa groups, respectively, within the following 6 days. Number of eggs and their hatchability laid during 10 days after the emergence are presented in Table 1. Number of eggs laid by the females treated with 0.004 and $0.02 \%$ hempa did not significantly differ from the untreated females. However, the egg number of females treated with 0.1 and $0.25 \%$ hempa decreased remarkably to about $1 / 2$ or less than $1 / 10$, respectively, of the untreated ones. Hatchability of eggs decreased in proportion to the rise of hempa concentration, and the eggs oviposited by 0.1 and $0.25 \%$ hempa groups were completely sterilized.

\section{Effect of hempa on the ovarian development}

Ovarian weight and follicle size of the ovaries at 4 days after emergence are shown in Table 2. The ovarian weight and the

Table 2 Effect of hempa on the ovarian development of the housefly at 4 days after emergence

\begin{tabular}{c|c|c}
\hline $\begin{array}{c}\text { Concentration } \\
\text { of hempa } \\
(\%)\end{array}$ & $\begin{array}{c}\text { Ovarian } \\
\text { weight* } \\
(\mathrm{mg})\end{array}$ & $\begin{array}{c}\text { Follicle } \\
\text { size** } \\
(\mathrm{mm})\end{array}$ \\
\hline untreated & $10.4 \pm 1.5^{* * *}$ & $1.29 \pm 0.03^{* * *}$ \\
0.004 & $10.3 \pm 1.9$ & $1.29 \pm 0.09$ \\
0.02 & $10.5 \pm 1.9$ & $1.27 \pm 0.08$ \\
0.1 & $5.5 \pm 2.4$ & $0.75 \pm 0.46$ \\
0.25 & $1.3 \pm 0.6$ & $0.30 \pm 0.07$ \\
\hline
\end{tabular}

* Flesh weight of a pair of ovaries

** longitudinal diameter of follicle

$* * *$ mean $\pm \mathrm{SD}$

follicle size in the ovary treated with 0.004 and $0.02 \%$ hempa were just the same as in the untreated females. The ovarian weight of 0.1 and $0.25 \%$ hempa groups decreased to about $1 / 2$ and $1 / 8$, respectively, of the untreated ones. The follicle size of 0.1 and $0.25 \%$ hempa groups decreased to about $3 / 5$ and $1 / 4$, respectively, of the untreated ones.

Table 1 Effect of hempa on the egg production and hatchability of the housefly. Hempa was fed continually to both sexes of flies immediately after emergence. Egg production and hatchability were scored on the eggs oviposited for 10 days after emergence.

\begin{tabular}{c|c|c|c|c}
\hline \multirow{2}{*}{$\begin{array}{c}\text { Concentration } \\
\text { of hempa } \\
(\%)\end{array}$} & \multicolumn{2}{|c|}{ Number of eggs* } & $\begin{array}{c}\text { Per cent } \\
\text { of } \\
\text { hatch }\end{array}$ & $\begin{array}{c}\text { Per cent } \\
\text { of } \\
\text { sterility }\end{array}$ \\
\cline { 2 - 4 } oviposited & hatched & 1560 & 91.1 & 0 \\
\hline untreated & 1712 & 715 & 48.0 & 47.3 \\
0.004 & 1489 & 248 & 28.0 & 69.3 \\
0.02 & 1377 & 0 & 0 & 100 \\
0.1 & 845 & 0 & 0 & 100 \\
0.25 & 131 & & & 0 \\
\hline
\end{tabular}

* average of 10 females 


\section{Histological changes in the ovary}

For determination of developmental stage of housefly ovaries, the stage definition described by Sakurai (1973) was employed to represent the growth state of the follicles in the ovaries at 4 days after emergence. Histological features of the ovary observed were as follows:

Untreated: Developmental stage of the follicles corresponded to Stage 7 . The mature oocyte has been enveloped in the chorion, and the yolk spheres have been homogeneously distributed in the ooplasm (Fig. 1).

$0.004 \%$ hempa: Developmental stage of the follicles was at Stage 7. Vacuolization was induced conspicuously in the ooplasm of many oocytes, especially in the periplasm (Fig. 2).

$0.02 \%$ hempa: Developmental stage of the follicles was at Stages 6 or 7 . Most of the Stage 7 oocytes were vacuolized, and the follicles at Stage 6 seemed normal. (Fig. 3).

$0.1 \%$ hempa : Developmental stage of the follicles remained at Stages 5 or 6 . The follicles at Stage 6 seemed to be normal except for a few disorganization observed in the follicular epithelial cells. Many kinds of abnormalities, as described below, were observed in the nurse cell nuclei of the follicles at Stage 5 ; nuclei became bizarre shape and stained more densely (Fig. 4), chromatin was thickened and thread-like (Fig. 5), and chromatin granules were numerous and of various sizes (Fig. 6). Cell fragments positive for the hematoxylin were found abundantly in the intensely damaged follicles, and the nurse cell nuclei became dissoluted (Fig. 7). Collapse and emptying of the first follicles were observed, and enlargement of the 2nd-follicles was not seen in the most severely damaged ovary (Fig. 8).

$0.25 \%$ hempa: Developmental stage of the follicles was suppressed to Stage 2 to 4 . Pycnosis of the nurse and follicular epithelial cell nuclei was distinctly observed in many follicles at Stage 4 (Fig. 9). The nurse cell nuclei of some follicles at Stage 4 were stained densely and the vacuoles were localized numerously in the follicles (Fig. 10). Bubbled state of chromatin was observed frequently in the nurse cell nuclei of follicles at Stage 3 (Fig. 11). Chromatolysis and disap- pearance of nuclei were induced occasionally in the nurse cells of the Stage 3 follicles (Figs. 12, 13). The nurse and follicular epithelial cells of the Stage 3 follicles were remarkably pycnotic, and the 2nd-follicles and the germarium were collapsed; blobs derived from the cystocytes were irregularly distributed in the germarium. (Figs. 14, 15). The Stage 2 follicles of the severely damaged ovary were degraded, and the cell fragments were localized abundantly in these follicles (Fig. 16).

\section{Histological features in the fat body}

Histological features of the abdominal fat body were studied in the females at 4 days after emergence. The fat body of normal females looked to be scarce of cytoplasmic materials (Fig. 17). Although the size of the fat body cells of the $0.25 \%$ hempa treated females were similar to the normal ones, vacuolization was intensely accompanying increased stainability (Fig. 18).

\section{DISCUSSION}

Continual feeding with hempa of both the sexes of housefly induced decline of hatchability at the low hempa concentration below $0.02 \%$ and decrease of egg number accompanying complete sterility at the high hempa concentration above $0.1 \%$ (Table 1 ). Conspicuous decrease of the egg number observed at high hempa concentration coincides well with the trend by Ogata et al. (1966). Marked sterilization observed indicates the combined dominant lethal effect of hempa against both sexes.

Ovarian weight and follicle size of the ovary at 4 days after emergence decreased intensely by the treatment with the high hempa concentration above $0.1 \%$ (Table 2). It is estimated that diminished egg production at high hempa concentration may reflect the depressed ovarian development. Suppressions of ovarian development by the treatment of aziridine compounds were reported in many insect species such as the housefly (Morgan and LaBrecque, 1962, 1964), the fruitfly (Cantwell and Henneberry, 1963), the screw-worm fly (Crystal and LaChance, 1963), the stablefly (Chamberlain and Barrett, 1968), the eye gnats (Schwartz, 
1965), the german cockroach (Smittle et al., 1966), the silkworm (Sugai, 1967) etc. As the results of the present study, similar effect was ascertained as to a non-aziridine chemosterilant, hempa.

Many kinds of abnormalities were observed histologically in the ovaries at 4-days of adult age treated with hempa: Vacuolization was frequently induced in the ooplasm, especially in the periplasm of the mature eggs by low concentration of hempa (Fig. 2). The vacuolization of ooplasm would be resulted from suppressed vitellogenesis of the follicle. Considering the fact that the periplasm plays an important role for the embryogenesis (Telfer and Anderson, 1968), the abnormality of ooplasm induced by hempa would be the main cause of the sterility of eggs. Malformed nuclei were observed in the nurse cells of the follicles treated with $0.1 \%$ hempa (Figs. 4 to 6 ) and $0.25 \%$ hempa (Figs. 10 to 13), which seemed to be the cytological changes preceding to the degradation of nurse cell nuclei. Same kinds of cytological changes were observed in the gamma-irradiated Drosophila ovary (King, 1957 a, b).

Pycnosis of nurse and follicular epithelial cell nuclei was induced in many follicles at

\section{Explanation of Plates}

Histological changes in the ovary and the fat body of female housefly at 4-days of adult age treated with hempa

(Hematoxylin and eosin staining)

Fig. 1 The follicle in untreated ovary. Yolk spheres homogeneously distribute in the ooplasm. $(\times 200)$

Fig. 2 The follicle in the ovary treated with $0.004 \%$ hempa. Vacuolization is observed in the ooplasm, especially in the periplasm. ( $\times 200)$

Fig. 3 The follicles in the ovary treated with $0.02 \%$ hempa. Growth of the follicles has been delayed and remained at Stage $6 . \quad(\times 100)$

Fig. 4-8 The follicles in the ovary treated with $0.1 \%$ hempa.

Fig. 4 Localization of bizarre shaped nurse cell nuclei, stained densely by hematoxylin. $(\times 200)$

Fig. 5 Localization of thickened thread like chromatin in the follicle. $(\times 200)$

Fig. 6 Distribution of chromatin granules in the nurse cell nuclei. $(\times 200)$

Fig. 7 Distribution of chromatin fragments and dissolution of nurse cell nucleus in the remarkably damaged follicle. $(\times 200)$

Fig. 8 Collapse and emptying of the follicles; no enlargement of the 2nd-follicles is seen in the most severely damaged ovary. ( $\times$ 40)

Fig. 9-16 The follicles in the ovary treated with $0.25 \%$ hempa.

Fig. 9 Pycnosis of the nurse and follicular epithelial cells in the follicles at Stage 4. $(\times 100)$

Fig. 10 Densely stained nurse cell nuclei and vacuolization of follicles. $(\times 100)$

Fig. 11 Bubblings of chromatin in the nurse cell nuclei. $(\times 200)$

Fig. 12 Chromatolysis of nurse cell nucleus. $(\times 200)$

Fig. 13 Disappearance of nurse cell nucleus. $(\times 200)$

Fig. 14 Pycnosis of the nurse and follicular epithelial cells in the follicles at Stage 3. $(\times 200)$

Fig. 15 Collapse of the 2nd-follicles and germarium; the blobs derived from the cystocyte are distributed in the germarium. $(\times 400)$

Fig. 16 Degradation of follicles remained at Stage 2 in the severely damaged ovary. $(\times 400)$

Fig. 17 The fat body of untreated females at 4-days of adult age; each cell looks to be scarce of cytoplasmic material. $(\times 400)$

Fig. 18 The fat body of females of 4 -days of adult age treated with $0.25 \%$ hempa, each cell is vacuolized conspicuously and stained densely. $(\times 400)$ 

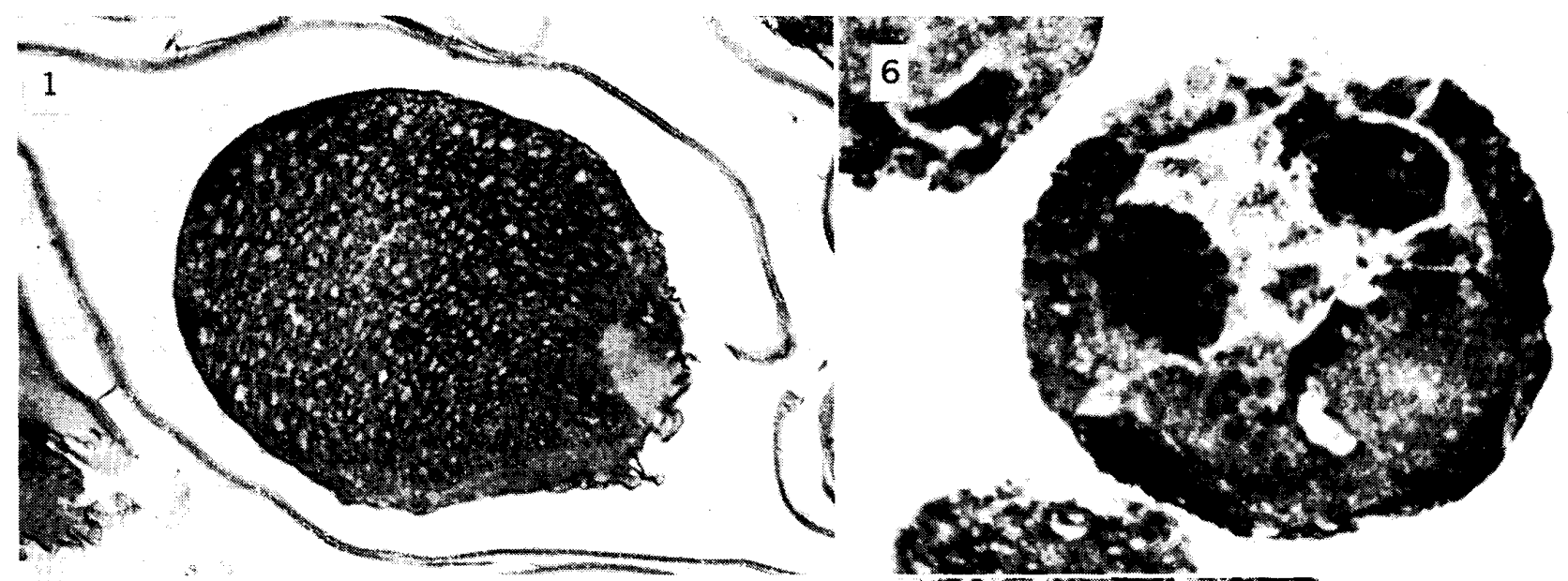

2

\section{5}

6.t.

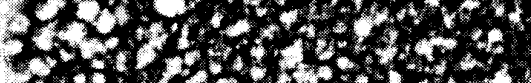

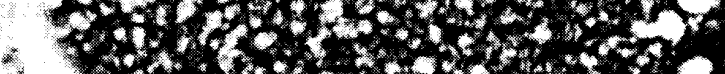

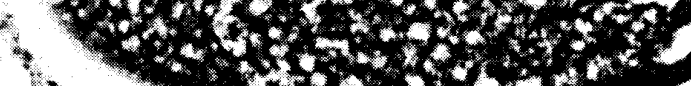

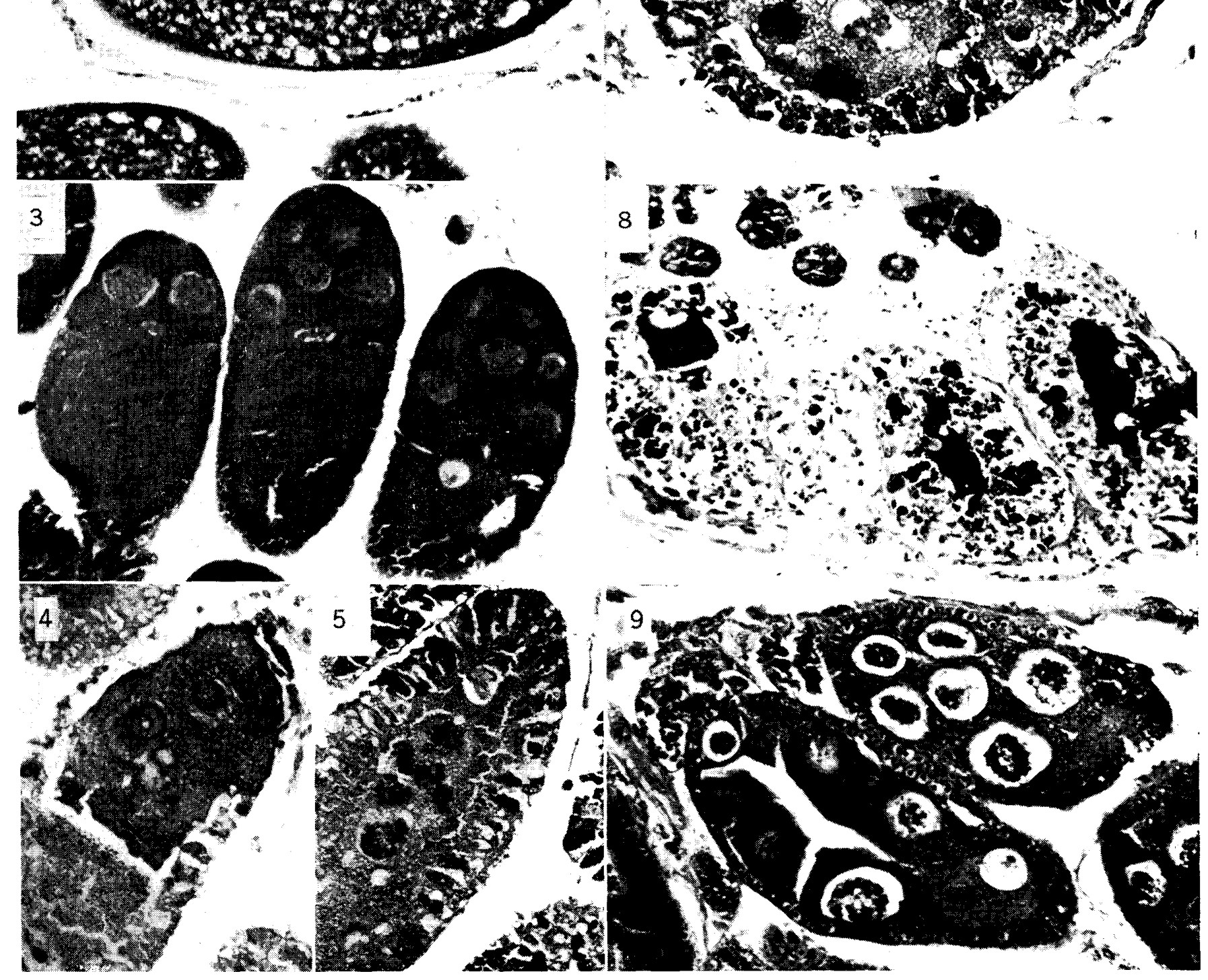

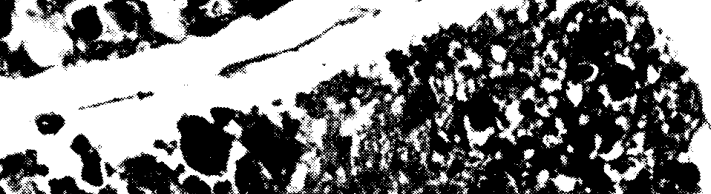

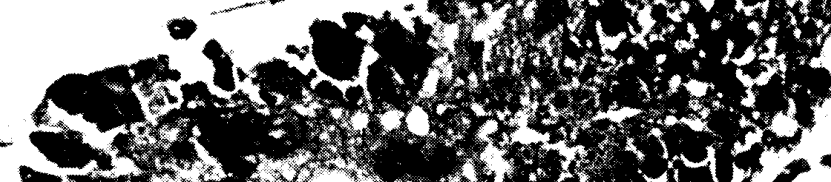
T.t. 8 है

- 20 \& 40

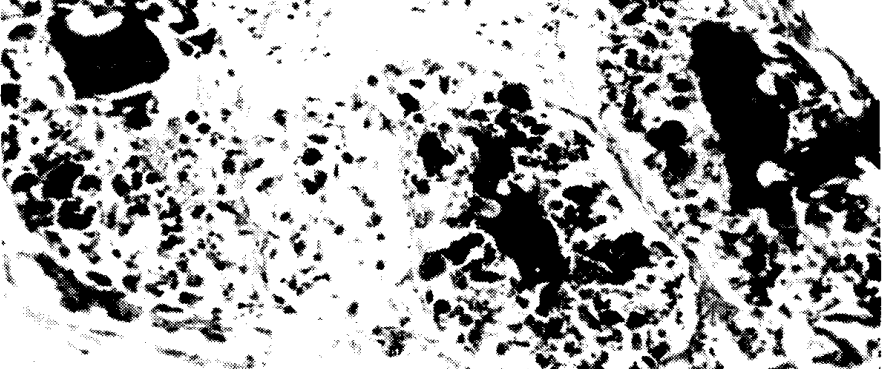

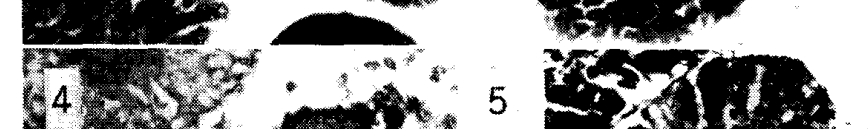

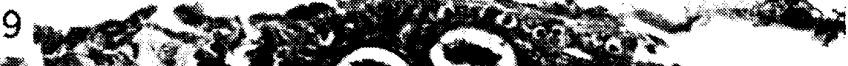

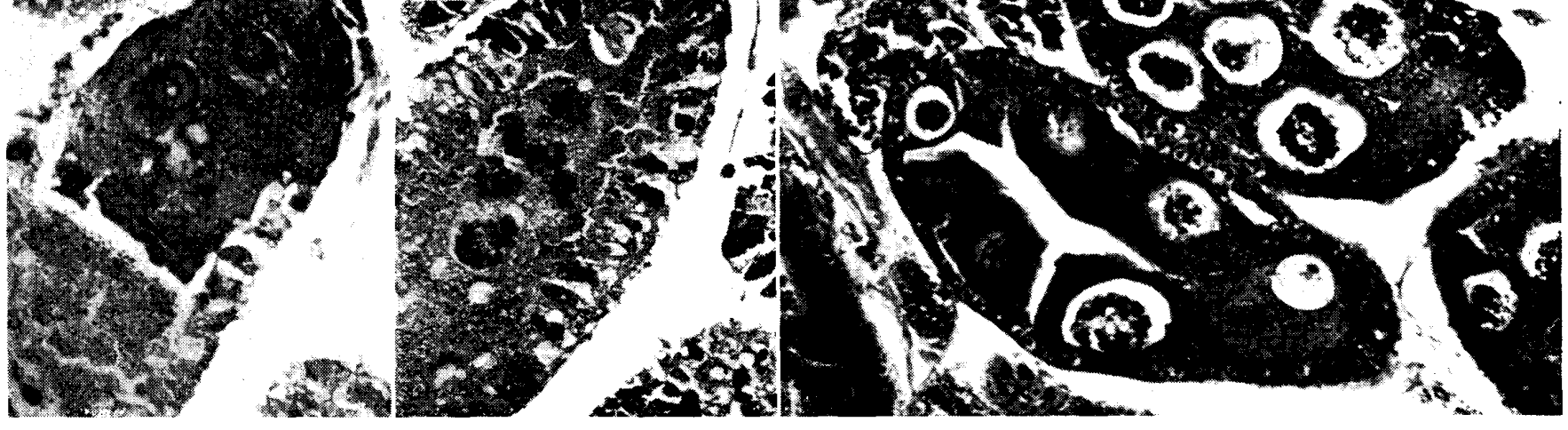



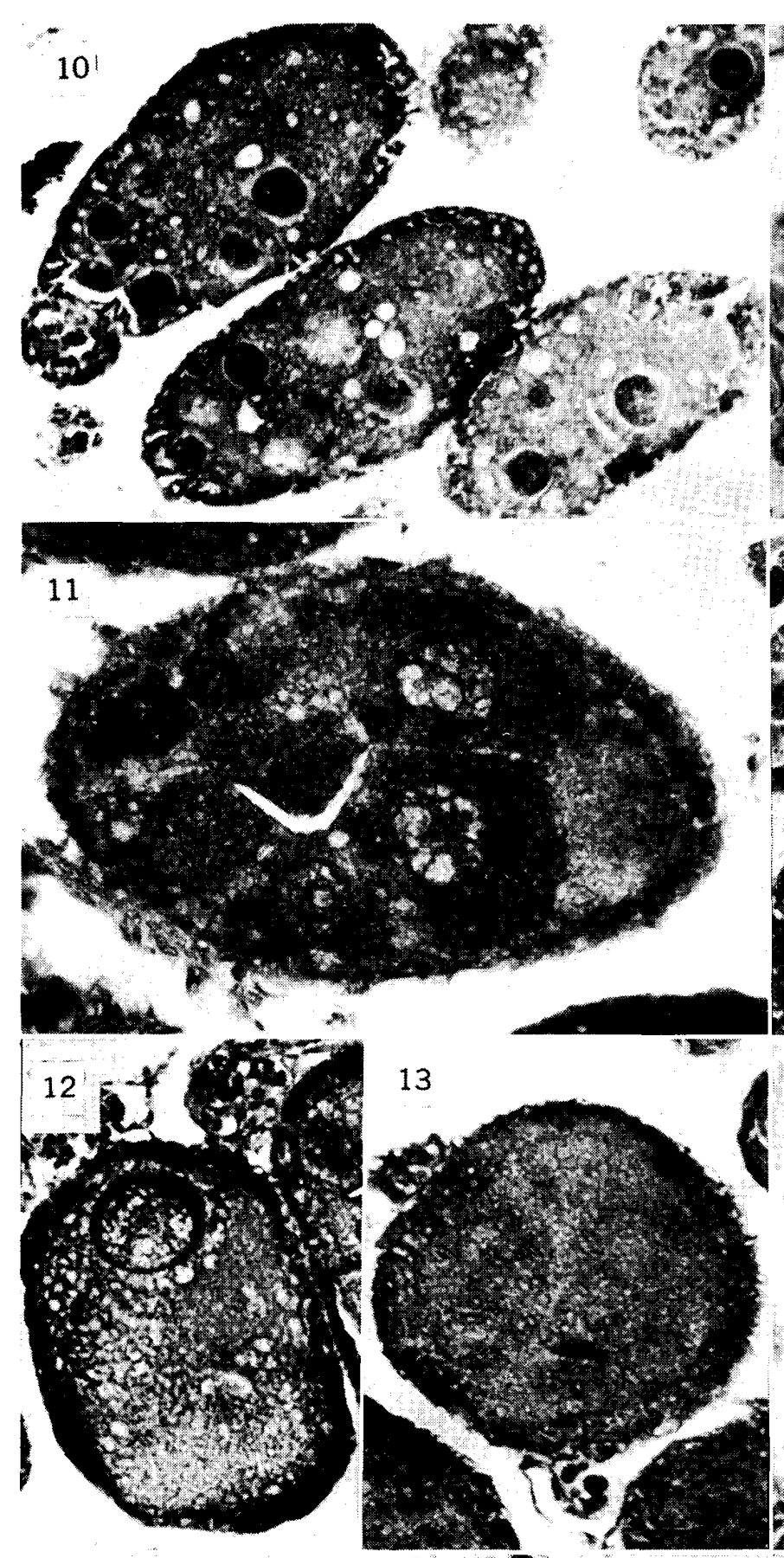

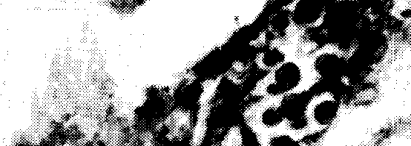

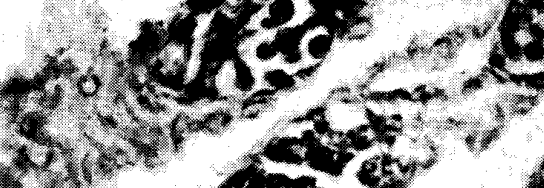

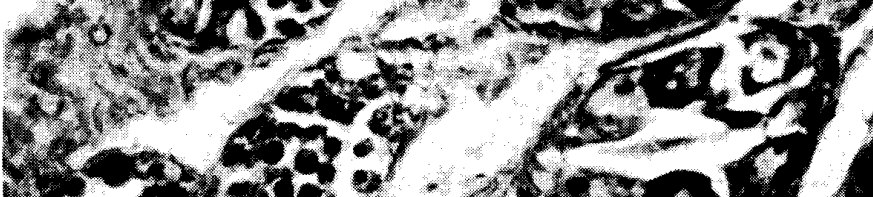

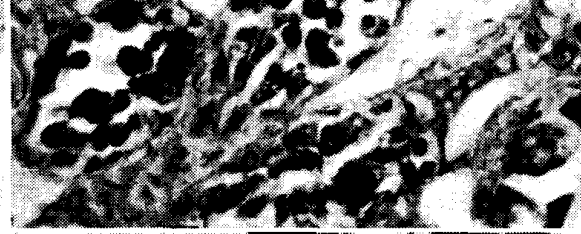

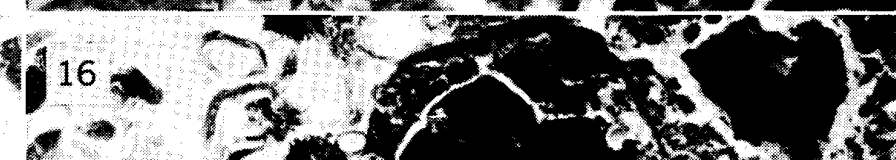

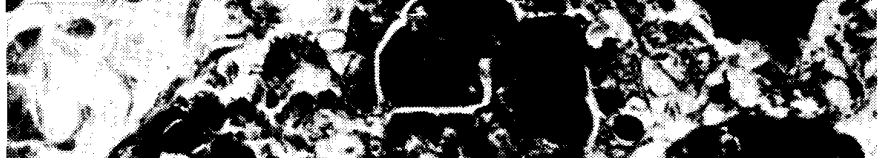

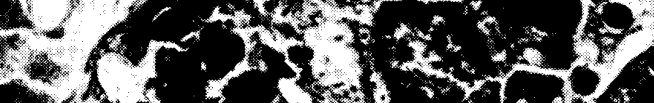

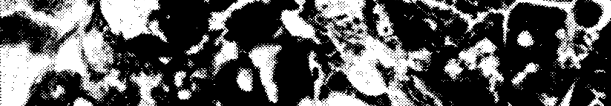
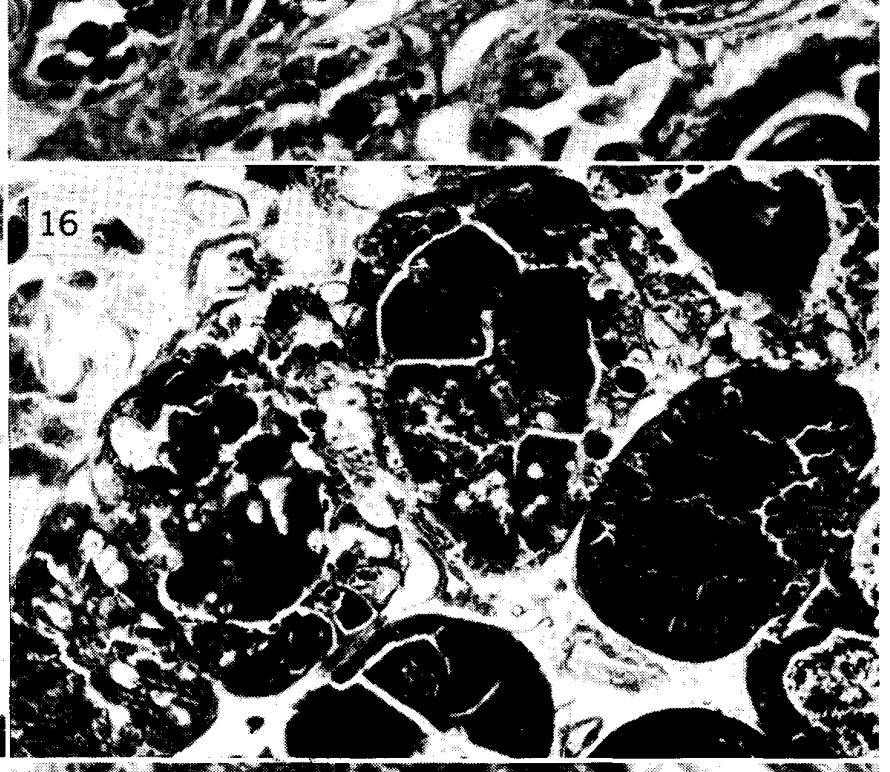

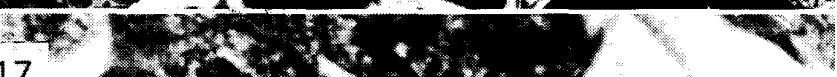

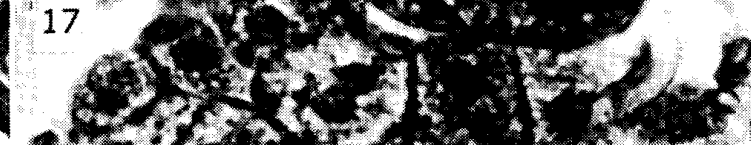

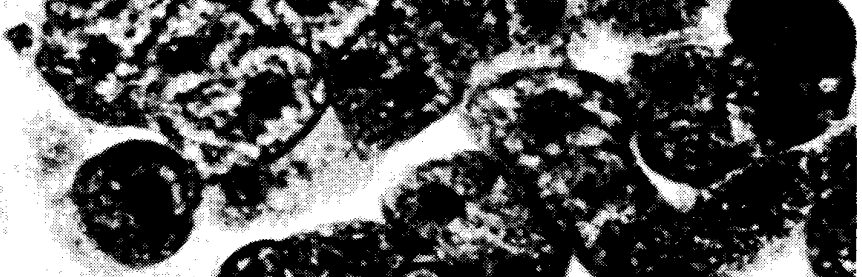

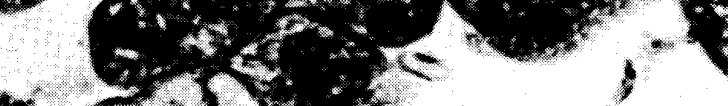

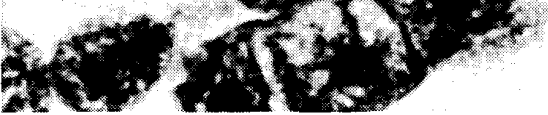

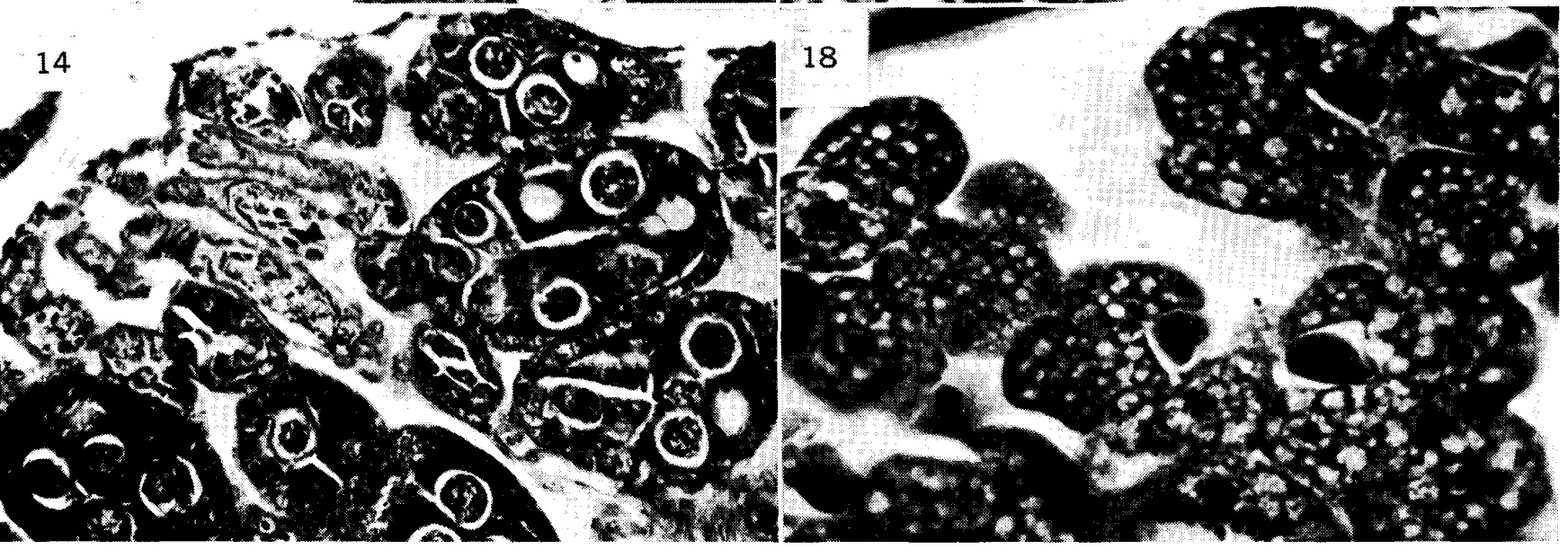


Stages 3 and 4 treated with $0.25 \%$ hempa (Figs. 9, 14). Considering the remarkably suppressed egg production at $0.25 \%$ of hempa, the pycnosis in the follicles would have concerned in causing inhibited oogenesis. Cell fragments observed in the damaged follicles (Figs. 7, 16) will represent the collapsed chromatin derived from the nurse and follicular epithelial cell nuclei. Lack of the 2nd-follicle enlargement (Fig. 8) as well as collapse of the 2nd-follicle and germarium (Fig. 15) induced by the treatment with hempa above $0.1 \%$ would also indicate marked inhibition of the 2 nd oogenesis.

Hempa also induced abnormal changes in the fat body of females (Fig. 18). Increased stainability of the fat body cells indicates increased deposition of oogenetic substance in the fat body due to inhibition of oogenesis by hempa. Conspicuous vacuolization in the fat body cells seems to be a symptom indicating disturbed living state of the flies.

The results obtained in the present study suggest that sterilizing effect of hempa to female housefly may be due to the disturbance of vitellogenic process by the low concentration of hempa and to the malfunctions of the germarium and the nuclei of nurse and follicular epithelial cells induced by the high concentration of hempa. Abnormalities observed in the fat body as well as in the ovary would indicate the systemic effect of hempa to the female housefly.

\section{ACKNOWLEDGEMENTS}

The author wishes to express his sincere thanks to Prof. N. Kumada, chief of the Department of Medical Zoology, Nagoya University School of Medicine, for his critical reading of the manuscript. Special thanks are also due to Yamanouchi Pharmacy for supplying the samples of chemosterilant.

\section{REFERENCES}

Cantwell, G. E. and T. J. Henneberry (1963): The effecs of gamma radiation and apholate on the reproductive tissues of Drosophila melanogaster Meigen. J. Insect Pathol., 5 : 251-264.

Chamberlain, W. F. and C. C. Barrett (1968): Incorporation of tritiated thymidine into the ovarian DNA of stable flies: Effect of treatment with apholate. Nature, $218: 471-472$.
Chang, S. C., P. H. Terry and A. B. Bořkovec (1964) : Insect chemosterilants with low toxicity for mammals. Science, 144 : 57-58.

Crystal, M. M. and L. E. LaChance (1963) : The modification of reproduction in insects treated with alkylating agents. I. Inhibition of ovarian growth and egg production and hatchability. Biol. Bull., 125 : 270-279.

King, R. C. (1957a) : Oogenesis in adult Drosophila melanogaster. III. Radiation-induced ovarian tumors. Growth, 21 : 129-135.

King, R. C. (1957 b) : The cytology of the irradiated ovary of Drosophila melanogaster. Exptl. Cell Res., 13 : 545-552.

King, R. C., R. G. Burnett and N. A. Staley (1957): Oogensis in adult Drosophila melanogaster. IV. Hereditary ovarian tumors. Groweth, 21 : 239-261.

Morgan, P. B. and G. C. LaBrecque (1962) : The effect of apholate on the ovarian development of house flies. J. Econ. Entomol., 55 : 626-628.

Morgan, P. B. and G. C. LaBrecque (1964): Effect of tepa and metepa on ovarian development of house flies. J. Econ. Entomol., 57 : 896-899.

Ogata, K., I. Tanaka and T. Suzuki (1966) : Observations on the chemosterilization of two alkylating agents, metepa and hempa on house flies. Jap. J. Sanit. Zool., $17: 201-204$ (in Japanese).

Sakurai, H. (1973) : Studies on the ovarian development in the housefly, Musca domestica vicina Macquart. I. Stages of oogenesis and the function of the follicle. Japan. J. Med. Sci. Biol., 26 : 239-248.

Schwartz, P. H., Jr. (1965) : Effect of apholate, metepa, and tepa on reproductive tissues of Hippelates pusio Loew. J. Invert. Pathol., 7 : 148-151.

Smittle, B. J., J. B. Schmitt and G. S. Burden (1966) : Effects of tepa on the reproductive organs and embryogeny of the german cockroach. J. Econ. Entomol., 59 : 1419-1423.

Sugai, E. (1967) : Effect of apholate on reproductive organ of the female silkworm, Bombyx mori, with special reference to histopathological observation of the ovaries. Jap. J. appl. Ent. Zool., 11 : 66-70 (in Japanese).

Telfer, W. H. and L. M. Anderson (1968): Functional transformations accompanying the initiation of a terminal growth phase in the cecropia moth oocyte. Develop. Biol., $17: 512-$ 535. 


\section{摘 要}

イエバエの卵巣発育に関する研究

II. 化学不妊剂 hempa の卵巣発育に 対する影響

イエバエの卯肾の発育機構に関する研究と関連して, イエバェの卵单発育に対する昆虫不妊剂 hempaの影響 を検討した。

hempa を餌に混ぜ，羽化後雌雄にともに継続して攝 食させたところ，0.02\%以下の低濃度の hempa の処 理により餒化率の顕著な低下がみられ，0.1\%以上の高 濃度の hempa により産卵数の著しい減少と孵化の完全 な抑制が示された。 また正常な卵巣の成熟期である羽化
後 4 日目の卵巣の発育状態を検討した結果, 卵䉾の生重 量および卵胞の大きさは, hempa の処理濃度の增加に 伴い急激に低下する傾向を示した.

一方, hempa 処理卵巣について 組織学的に観察した 結果, 低濃度の hempa により成熟卵胞の卵質は著しく 空胞化し, 高濃度の hempaにより栄養細胞执よび卵胞 上皮細胞における核濃縮と核の崩壊・退化，ゲルマリウ 厶の崩壊, 第 2 卯胞の発育抑制等の細胞学的変化が示さ れた. また hempa 処理雌の脂肪体についても細胞の著 しい空胞化が観察された。

以上の結果より，hempa はイエバエの 䧳性生殖細胞 に対しても雄性生殖細胞におけると同稼に強力に作用 し，正常な卵形成過程を攪乱することにより雌性不妊の 効果を示すものと推察された。 